\title{
KEKUATAN MUSIK DALAM PENDIDIKAN KARAKTER MANUSIA
}

\author{
Adi Putra Panjaitan ${ }^{1}$ Graduate Student of Theology \\ Faculty of Philosophy \\ Parahyangan Catholic University \\ Bandung, Indonesia
}

\begin{abstract}
:
Generally, listening to music is a fun activity to almost everyone. Furthermore, music can be used as an entertainment and a means of expressing the self. Music can be found everywhere easily, whether in private or in public places, and it has become part of human life. In this article, the author explores the power of music through its particular elements in relation to human character education. In other words, music is considered to have influences in shaping the character of the self, albeit in daily experiences music is often seen as merely entertainment. The elements of music, which includes melody, rhythm, harmony, beat, dynamics, timbre, and lyrics, are correlated to the effects each may bring towards the listeners. In this approach, music is considered to have a transformative role in shaping and orienting the character of the listener, since the person is not merely focused on the thinking mind, but to the sensitivity of the self perceiving the sound of music.
\end{abstract}

Keywords:

music $\bullet$ character building $\bullet$ musical elements $\bullet$ self $\bullet$ education $\bullet$ transformation 


\section{Pendahuluan}

Secara etimologis, karakter berasal dari bahasa Yunani karasso yang berarti cetak biru, format dasar, sidik seperti dalam sidik jari. ${ }^{2}$ Karakter mengacu pada sifat-sifat kejiwaan, akhlak, tabiat, dan watak yang membedakan seseorang dengan yang lain. ${ }^{3}$ Dalam tradisi Yahudi, karakter dimengerti sebagai sesuatu yang tidak dapat dikuasai oleh manusia, seperti halnya alam yang memiliki karakter dan kebebebasannya sendiri. ${ }^{4}$ Berkaitan dengan itu, E. Mounier ${ }^{5}$ menafsirkan karakter ke dalam dua pengertian. Pertama, sebagai sekumpulan kondisi yang diberikan begitu saja, yang lebih kurang dipaksakan dalam diri kita (given). Kedua, karakter dipahami sebagai kemampuan seseorang dalam mengatasi kondisi tersebut (willed) ${ }^{6}$ Sementara itu, G. Allport, seorang psikolog Amerika, membedakan antara karakter dan kepribadian. Menurutnya, karakter merupakan hal yang dapat dievaluasi (dinilai), sedangkan kepribadian tidak dapat dinilai ataupun diubah. $^{7}$

Ketika berbicara mengenai karakter, orang dapat menggunakan pendekatan genetis atau keturunan. Pendekatan ini memberikan tekanan pada pola perilaku yang didasarkan pada struktur genetis keluarga. Faktor genetis adalah bawaan sejak lahir dan merupakan pengaruh dari sifat yang dimiliki oleh salah satu dari kedua orang tua atau bisa gabungan dari keduanya. Pemikir yang mengembangkan pendekatan genetis ini adalah G. J. Mendel. ${ }^{8}$ Ia berpandangan bahwa sifat anak memiliki kemiripan dengan sifat orang tuanya. Hal ini dapat dianggap masuk akal, karena anak mewarisi sebagain karakter orang tuanya. Meskipun demikian, manusia tetap mempunyai keunikannya masing-masing yang tidak sepenuhnya dapat terungkap. Berbagai cara dan upaya yang dilakukan untuk memahami karakter manusia tidak dapat sepenuhnya tercapai. Selalu ada sisi 'misteri' dalam diri manusia. Meskipun demikian, manusia tidak menyerah pada sisi naturalnya saja. Telaah mengenai karakter bisa mendorong pada pemahaman tentang proses pembentukan diri manusia.

Tulisan ini mengeksplorasi dinamika pembentukan karakter dan diri manusia melalui musik sebagai salah satu alternatif yang bisa dikembangkan dewasa ini. Meskipun pendekatan ini bukan merupakan sesuatu yang baru dalam dunia pendidikan, ada perspektif lain yang mungkin bisa ditemukan. Dalam konteks Indonesia, pemanfaatan 
musik sebagai sarana pendidikan karakter tampaknya masih kurang. Musik cenderung dipersepsi sebagai sarana hiburan atau ekpresi diri. Pemanfaatan musik dalam pembentukan karakter bisa sangat bermanfaat bagi dunia pendidikan, khususnya kepada kaum remaja yang cenderung rentan dipengaruhi berbagai hal di masyarakat.

\section{Pendidikan Karakter}

Istilah 'karakter' dipakai secara khusus dalam konteks pendidikan pada akhir Abad ke-18. ${ }^{9}$ Terminologi ini mengacu pada pendekatan "idealisspiritualis"10 dalam pendidikan yang juga dikenal sebagai teori pendidikan normatif. Dalam sejarah, pendidikan karakter telah menjadi tanggung jawab bersama para orang tua, guru, dan anggota masyarakat, yang bekerja sama untuk mendukung pengembangan karakter anak. Pendidikan karakter adalah proses pembelajaran yang memungkinkan anak dan orang dewasa dalam komunitas sekolah untuk memahami, peduli, dan bertindak berdasarkan nilai-nilai etika, seperti sopan-santun, keadilan, kebajikan sipil dan kewarganegaraan, serta tanggung jawab pada diri sendiri dan terhadap orang lain. Pendidikan karakter juga mengajarkan kebiasaan dalam pikiran dan perbuatan untuk hidup bersama dengan orang lain sebagai keluarga, teman, tetangga, masyarakat, dan bangsa.

Dari perkembangan tersebut, pendidikan karakter pada dasarnya telah menjadi bagian inti sejarah pendidikan. Hal itu dapat ditemukan dalam cita-cita yang muncul dari Paideia Yunani, Humanitas Romawi, dan pedagogi kristiani, yang secara umum mengarah pada pendidikan karakter. ${ }^{11}$ Yang menarik dari pendidikan tersebut ialah bahwa pengembangan kualitas moral seseorang ditempa juga melalui pengajaran musik, yakni dengan cara mengajarkan memetik harpa kepada anak-anak, serta membacakan syair-syair puisi diiringi dengan dentingan gitar yang sifatnya ritmis dan harmonis. Masyarakat pada masa itu percaya bahwa melalui pembelajaran musik, seseorang dapat menemukan keseimbangan dan harmoni di dalam jiwanya. ${ }^{12}$

Musik adalah bagian dari kehidupan manusia. Dalam kehidupannya, kebudayaan manusia hampir selalu memunculkan keberadaan musik. Karena terkait dengan kehidupan manusia, musik pun terkait dengan karakter manusia. Unsur-unsur musik juga dapat ditemukan dalam kebudayaan-kebudayaan tertentu, misalnya, ketika musik dipergunakan 
untuk berdoa, memuji leluhur, memeriahkan pesta adat, dan acara-acara penting lainnya. Selain dijumpai dalam kebudayaan tertentu, musik dapat dijumpai pula di berbagai bidang kehidupan lain. Oleh karenanya, musik bisa memengaruhi karakter manusia, dan berdasarkan asumsi ini, musik dapat digunakan pula dalam proses pendidikan karakter. Berikut akan diungkapkan beberapa aspek musik dan kemungkinan kaitan serta perannya dalam pendidikan karakter melalui korelasi eksploratif dan konstruktif.

\section{Musik dan Kekuatannya}

Musik merupakan bagian dari seni yang menggunakan bunyi sebagai medium. Bunyi yang dimaksud di sini bukanlah sembarang bunyi, seperti bunyi klakson, sepeda motor, mobil, radio, televisi, atau bunyi lain yang sering didengar sehari-hari. Bunyi dalam musik ialah bunyi yang teratur, sehingga memiliki daya tarik terhadap setiap orang yang mendengar dan memaknainya. Bunyi dalam musik ialah bunyi yang mempunyai aturan, harmoni, dan tujuan. ${ }^{13}$ Mengenai hal ini Aaron Copland dalam What to listen for in Music menyebutkan empat elemen dasar musik, yakni ritme, melodi, harmoni, dan warna suara. ${ }^{14}$ Jumlah yang berbeda ditemukan dalam pandangan Joseph Machlis, yang menyebutkan enam elemen dasar musik, yaitu melodi, harmoni, ritme, tempo, dinamika, dan warna suara. ${ }^{15}$ Meskipun unsur 'lirik' tidak pernah digolongkan sebagai elemen dasar musik, dalam tulisan ini dimasukkan sebagai elemen yang juga penting dalam musik, khususnya dalam kaitan dengan pendidikan karakter. Alasannya ialah bahwa unsur lirik dalam musik bisa sangat mempengaruhi karakter pendengarnya. Ada pula jenis musik tertentu yang bisa mempengaruhi pendengarnya tanpa menggunakan lirik sebagai salah satu medianya, misalnya, musik-musik meditatif. Dalam tulisan ini, unsur 'lirik' diperhitungkan sebagai salah satu kekuatan musik, karena mampu mempengaruhi pendengarnya secara langsung melalui kemampuan pemahamannya. Sebagai contoh, lagu kebangsaan "Indonesia Raya" secara tidak langsung dapat mempengaruhi warga negara Indonesia menjadi lebih nasionalis dalam kehidupan berkebangsaan. Di sebagian sekolah ada kebiasaan memperdengarkan lagu-lagu yang bertemakan kebangsaan dengan harapan bahwa murid-murid dapat bertumbuh dalam karakter kebangsaan. 
Kekuatan musik bisa ditemukan melalui elemen-elemennya, karena telah menjadi bagian yang tidak terpisahkan kehidupan manusia. Diri manusia yang hidup dan musik memiliki keterkaitan satu sama lain. Elemen-elemen yang ada dalam musik, seperti melodi, ritme, harmoni, dan warna suara, dapat ditemukan analoginya pada tubuh manusia. Tubuh manusia dapat dibayangkan seperti musik yang juga kaya akan melodi, diwarnai ritme, tersusun dari harmoni, dan sarat dengan makna. ${ }^{16}$ Oleh karena itu, tidak mengherankan apabila manusia bisa menangkap dan memaknai musik, tanpa terlebih dahulu mempelajarinya secara kognitif. Berikut akan dieksplorasi elemen-elemen dasar musik, yang memperlihatkan kekuatan musik dalam kaitan dengan kehidupan manusia. Perpaduan antara elemen-elemen dasar ini mampu menghasilkan bunyi yang indah, sehingga berpengaruh pada para pendengarnya.

\section{Melodi}

Secara sederhana, melodi adalah susunan nada yang diatur tinggirendah dan polanya sehingga menjadi kalimat lagu. Melodi merupakan salah satu bagian penting dalam musik yang mampu menampilkan suasana sebuah lagu, baik itu sedih maupun gembira. Melodi bahkan disebut sebagai elemen musik terluas dan yang mampu menarik secara langsung perhatian pendengar. ${ }^{17}$ Melodi berbeda dari ritme, namun saling terkait. Jika gagasan tentang ritme dibayangkan oleh imajinasi, ia merupakan elemen fisiknya, sedangkan gagasan tentang melodi lebih diasosiasikan dengan emosi mental. ${ }^{18}$ Hal ini berarti bahwa melodi mempunyai peranan penting dalam musik, khususnya dalam menarik perhatian para pendengarnya. Tanpa melodi, sebuah musik bisa jadi akan kurang menarik untuk didengarkan.

Adele, ${ }^{19}$ seorang penyanyi ternama, pernah mengatakan di majalah Time, Desember 2015, bahwa musik merupakan ungkapan kegelisahan manusia terhadap masa lalu, masa kini, dan masa depan. Menurutnya, kegelisahan manusia diungkapkan lewat lagu dan ditonjolkan lewat lirik dan melodi yang mengiringinya. Hal ini menunjukkan kuatnya peran melodi dalam menghadirkan sekaligus menciptakan suasana tertentu dalam musik. Ketika lagu yang sama digubah ke dalam melodi yang berbeda, suasana yang dihasilkan pun akan berbeda. Artinya, peran melodi dalam musik adalah esensial terutama untuk menyampaikan isi lagu tersebut. Melodi mempunyai fungsi yang luas dalam musik, namun yang terpenting dalam 
sebuah melodi ialah kualitas ekspresifnya yang mampu membangkitkan respon emosional pendengarnya. ${ }^{20}$ Dengan kata lain, melodi yang baik ialah melodi yang mampu membangkitkan emosi pendengar musik. Jika kemampuan ini sudah dibawa oleh sebuah musik, daya guna musik itu dapat membawa manusia pada pengalaman yang transenden, yang melampaui pengalaman manusiawi melalui suara yang melodius.

\section{Ritme}

Secara harafiah ritme dimengerti sebagai perulangan bunyibunyian menurut pola tertentu dalam lagu. Perulangan bunyi-bunyian ini memunculkan keindahan, dan membuat lagu menjadi 'enak' didengar. Ini berarti unsur ritme mempunyai pengaruh kuat dalam merangsang musikalitas manusia. ${ }^{21}$ Ritme mampu mempengaruhi manusia secara emosional. Ketika suatu musik diperdengarkan dengan ritme yang lambat, seseorang bisa merasa lebih tenang dan mungkin masuk dalam suasana sakral. Sebaliknya, ketika sebuah lagu diperdengarkan dengan ritme yang cepat, seseorang akan terdorong untuk turut menggerakkan badan. Secara spontan, ritme dalam musik mampu menggerakkan manusia. Sebagai contoh, penduduk pedalaman Afrika hanya mendengar dua bunyi pukulan ritmis, namun bunyi itu dapat mengundang mereka untuk berkumpul dan menari. Bahkan bunyi sederhana tersebut dapat mengantar mereka pada pengalaman tentang yang ilahi dan ke dalam 'perjumpaan' (spiritual) dengan roh nenek moyang. Suharjo Parto dalam Musik Seni Barat dan Sumber daya Manusia mengutip salah satu tulisan Dailamy Hassan (1961:17) yang mengatakan bahwa satu-satunya unsur musikal yang dimiliki alam dan disediakan untuk manusia ialah ritme, sedangkan melodi dan harmoni harus dibuat oleh manusia sendiri. ${ }^{22}$ Hal itu mengandaikan bahwa ritme secara natural telah ada sebelum ditangkap oleh manusia. Meskipun telah dipraktikkan dalam musik suku-suku, penggunaan ritme menjadi pengetahuan baru diterapkan kemudian. Unsur ritme adalah unsur yang tampaknya paling primitif dibanding unsur-unsur musik lainnya (melodi, harmoni, tempo, dinamika, dan warna suara).

Dalam kehidupan sehari-hari, secara spontan orang mudah bereaksi ketika mendengar bunyi musik tertentu, baik bergoyang, menghentakkan kaki, memukul meja, menggoyangkan kepala, maupun melakukan gerakangerakan lain, sekaligus memunculkan perasaan seperti rasa takut, resah, 
dan gelisah. Hal itu dikarenakan pola ritme musik yang bisa langsung menembus sensibilitas manusia yang menikmatinya. ${ }^{23}$ Dengan kata lain, ritme yang dibawa oleh musik tampaknya berpadanan dengan ritme kegiatan manusia. Dalam kesehariannya, manusia pun menciptakan ritme tertentu, baik bernafas, berjalan, maupun mengunyah makanan. Detak jantung manusia pun merupakan 'ritme' dasar kehidupan manusia. Jika ritme dasar ini tidak berjalan dengan baik, kehidupan manusia itu tidak dapat berjalan. ${ }^{24}$ Serupa dengan hal tersebut, alam semesta pun mengenal hukumnya, yakni keteraturan-keteraturan dalam pergerakan: planet-planet, siklus musim dan badai, serta siang dan malam. Jika alam semesta tidak berada dalam ritme yang teratur ini, konsekuensi akan menimpa tidak hanya dirinya sendiri, tetapi juga seluruh ciptaan yang ada di dalamnya. Oleh sebab itu, ritme tidak hanya penting dalam musik dan diri manusia, tetapi juga dalam keseluruhan alam dengan semua ciptaan yang ada di dalamnya.

\section{Harmoni}

Harmoni berasal dari kata harmonia (Yunani) yang berarti terikat secara serasi. Harmoni memberikan kedalaman pada melodi, seperti halnya perspektif warna dalam lukisan. ${ }^{25}$ Harmoni menyangkut hubungan antara interval nada dan akor (paduan nada). Interval dapat dimengerti sebagai jarak antara dua nada. Akor dimengerti sebagai kombinasi antara tiga nada atau lebih dalam satu tekanan bunyi. ${ }^{26}$

Berdasarkan pergerakan melodi, harmoni dalam musik menambahkan dimensi lain, yakni kedalaman. Harmoni dalam musik adalah suatu perspektif penggambaran. Harmoni menjelaskan impresi di wilayah musik itu sendiri. Peran pendukung harmoni nyata ketika seorang penyanyi menggabungkan melodinya dengan akor-akor alat musik gitar atau banjo, atau ketika seorang pianis memainkan melodi dengan tangan kanannya sementara tangan kirinya memainkan akor. Ketika akor yang salah dibunyikan, orang mungkin tidak menyadari bahwa kesatuan melodi dan harmoni yang dibutuhkan menjadi rusak. ${ }^{27}$ Dalam hal ini penting sekali menaati atuan-aturan yang ada, sehingga dengan mengikuti aturan dalam musik akan tercipta suatu keharmonisan dalam musik. Hal ini tidak hanya berlaku dalam musik, tetapi juga di bidang-bidang kehidupan manusia. Keharmonisan dalam kehidupan bersama, misalnya, 
akan tercipta jika masing-masing anggota mengikuti aturan-aturan yang sudah ditetapkan. Sebaliknya, ketidakharmonisan akan terjadi jika salah satu anggota melanggar aturan yang telah ditetapkan. Dalam hal ini peran seorang individu sangat berpengaruh dalam menghadirkan keharmonisan. Ketika ada satu nada tidak berfungsi dengan baik, akan timbul efek ketidakharmonisan dalam musik. Begitu pula, jika salah satu anggota tidak melakukan tugas dengan semestinya, akan rusak kehidupan bersama.

Bila dilakukan analogi antara melodi dan harmoni, dapat ditemukan bahwa melodi begerak secara horizontal, sedangkan harmoni bergerak secara vertikal yang meliputi akor (blok-blok nada). Kedua elemen ini saling menyertai dan mempengaruhi dalam kebersamaan dengan ritme. Semua elemen tersebut bergerak dan mengalir dari suatu kombinasi nada ke kombinasi yang lain sehingga menampilkan keharmonisan nada-nada. Dalam diri manusia bisa ditemukan pula prinsip harmoni, misalnya, denyut jantung, aliran darah, tangan yang bekerja, hati yang merasa, mata yang melihat, dan berbagai organ pada manusia. Semuanya membentuk harmoni yang teratur, sehingga apa yang dikehendaki oleh tubuh dapat terlaksana. Dengan kata lain, semua organ tubuh dapat bekerja dengan baik karena ada harmoni, sebab tanpa harmoni, tubuh secara keseluruhan bisa sakit. Prinsip ini pun berlaku bagi alam semesta yang diciptakan Tuhan dengan keharmonisan. Tuhan telah menata sedemikian rupa pergerakan dalam keteraturan tata surya, misalnya, pemisahan antara air dan daratan, antara bumi dan langit, kehidupan tumbuhan, binatang, manusia, serta semua isi alam semesta. Dengan demikian, seluruh alam raya menjadi harmonis dan indah. Baik alam semesta maupum manusia membutuhkan harmoni agar menemukan kedamaian dan ketenangan.

Dalam kehidupan sehari-hari, harmoni membutuhkan keunikan dari setiap orang. Setiap pribadi memiliki bakat dan kemampuan yang berbeda-beda. Keindahan tampak ketika masing-masing pribadi memberikan diri untuk membentuk suatu harmoni. Akor dalam musik menjadi lebih hidup jika dibunyikan bersama dengan nada-nada lain. Demikian juga kehidupan bersama menjadi lebih indah jika masing-masing pribadi 'membunyikan' bakatnya bersama dengan pribadi-pribadi lain, dan dengan demikian tercipta suatu prinsip harmoni. 


\section{Tempo}

Roger Kamien dalam Music: An Appreciation mengartikan tempo sebagai kecepatan beat - kecepatan dasar musik. ${ }^{28}$ Sementara itu, Machlis mengartikannya sebagai ukuran cepat atau lambatnya sebuah lagu. ${ }^{29}$ Kedua pendapat mengenai tempo tersebut serupa, yakni ukuran waktu di dalam musik. Ketika sebuah lagu dibawakan dalam suasana gembira, tempo musiknya cenderung cepat. Sebaliknya, lagu yang bernuansa sedih dibawakan dalam tempo yang sedang atau lambat. Dalam hal ini, tempo bisa cepat atau lambat, tergantung suasana yang dibawakan dalam lagu tersebut. Oleh karena itu, sebelum memainkan musiknya, pemusik harus menyesuaikan tempo musiknya dengan lagu yang akan dibawakan. Hal itu dilakukan agar maksud yang ada dalam sebuah lagu benar-benar sesuai dengan maksud penciptanya. Tempo dalam musik pun sangat penting dalam menghadirkan musik yang indah dan berdaya guna.

Tempo dapat membawa implikasi-implikasi emosional. Seseorang cenderung mempercepat tutur katanya ketika merasa gelisah atau kebingungan. Tubuh cenderung bergerak cepat ketika bersemangat, dan melambat ketika dilanda kelesuan. Dalam pergerakan seni seperti halnya musik, tahapan pergerakan adalah faktor yang penting. Orang menanggapi tempo dalam musik secara fisik dan psikologis. Detak jantung, nafas, serta keseluruhan diri menyesuaikan dengan tahap pertumbuhan dan dengan perasaan waspada melalui kondisi alam sadar dan bawa sadar. ${ }^{30}$ Artinya, keadaan natural manusia selalu menyesuaikan diri dengan pergerakan atau tempo yang ada dalam musik.

Karena ada kaitan erat dengan perasaan manusia, tempo menampilkan karakter musik seperti halnya langkah kaki manusia. Istilahistilah tempo dalam musik umumnya berbahasa Italia, sebagai warisan zaman ketika opera Italia pernah mendominasi daratan Eropa. Dari daftar tempo, andante ('pergi'; Italia: andare, untuk pergi; to go) menunjukkan kecepatan yang normal dalam melangkah. Berikut kategori tempo di dalam musik: ${ }^{31}$

\begin{tabular}{|ll|ll|}
\hline Grave & : sangat lambat sekali & Allegro & : cepat (ringan) \\
Largo & : sangat lambat & Vivace & : ringan \\
Adagio & : agak lambat & Presto & : sangat cepat \\
Andante & : langkah normal & Prestissimo & : sangat cepat sekali \\
Moderato & : kecepatan sedang & Accelerando & : bertambah cepat \\
Allegretto & : agak cepat & Ritardando & : bertambah lambat \\
\hline
\end{tabular}




\section{Dinamika}

Kadang-kadang suatu lagu dinyanyikan dengan lembut pada awal, kemudian berangsur-angsur keras, atau mendadak keras, kembali melembut pada bagian tertentu, kemudian mengeras atau melembut pada bagian akhir. Perubahan-perubahan ini disebut dinamika, yang oleh Machlis diartikan sebagai ukuran keras atau lembutnya musik ketika dimainkan. ${ }^{32}$ Dalam wilayah ini, seperti juga dalam hal tempo, terkandung respon-respon yang berakar di alam emosi-emosi manusia. ${ }^{33}$ Ketakutan manusia rupanya bisa digambarkan dalam dinamika yang sedang, lembut, atau sangat lembut seperti orang yang berbisik, sedangkan kegirangan dan sorak-sorai cenderung digambarkan dengan dinamika yang keras. Emosi-emosi itu digambarkan seturut suasana yang diciptakan dalam musik. Ketika dinamika dimainkan secara tepat, para pendengar pun dapat terbawa arus musikal dan masuk ke dalam suasana sebuah lagu. Hal ini juga menjadi semacam prasyarat bagi seorang leader yang harus menguasai bermacam-macam dinamika dalam musik. Berikut jenis-jenis dinamika yang biasa digunakan dalam membawakan musik: ${ }^{34}$

\begin{tabular}{|lll|lll|}
\hline Pianissimo & $(\mathrm{pp})$ & $:$ sangat lembut & Forte & $(\mathrm{f})$ & : keras \\
Piano & $(\mathrm{p})$ & $:$ lembut & Fortissimo & $(\mathrm{ff})$ & $:$ sangat keras \\
Mezzo piano & $(\mathrm{mp})$ & $:$ agak lembut & Crescendo & $(<)$ & $:$ makin keras \\
Mezzo forte & $(\mathrm{mf})$ & $:$ agak keras & Descrescendo & $(>)$ & $:$ makin lembut \\
\hline
\end{tabular}

Dinamika merupakan kekuatan lain yang ditemukan dalam musik, terutama untuk merangsang perhatian dan mempengaruhi para pendengar. Elemen tersebut menjadi sangat penting ketika dikaitkan dengan emosiemosi manusia yang juga dapat berubah-ubah. Ada musik yang sifatnya bersemangat dan menggebu-gebu, namun di sisi lain ada musik yang menghadirkan suasana yang diwarnai kelesuan dan ketidakberdayaan.

\section{Warna Suara}

Perkembangan zaman mempengaruhi dunia musik. Pada suatu masa orang menikmati musik lewat suara-suara alam seperti aliran air, kicauan burung, dan hembusan angin. Kini manusia bisa juga menikmati musik lewat alat-alat yang diciptakan, seperti piano, gitar, dan biola. Masing-masing alat musik mempunyai ciri khasnya, baik dalam hal suara maupun bentuk. Dalam musik, perbedaan karakter suara disebut sebagai 
timbre (warna suara). ${ }^{35}$ Kamus Besar Bahasa Indonesia mengartikan timbre sebagai perbedaan sifat antara dua nada yang sama kuatnya dan sama tinggi nadanya. ${ }^{36}$ Sementara itu, Aaron Copland dalam What to Listen for in Music mengartikan timbre sebagai kualitas suara yang dihasilkan oleh media produksi nada musik tertentu. Timbre dalam musik ibarat warna dalam lukisan. ${ }^{37}$ Banyaknya warna di dalam sebuah lukisan membuatnya semakin indah dan menarik untuk dipandang.

Demikian juga halnya dengan musik. Semakin beragam alat musik yang digunakan, suasana yang dihasilkan pun akan semakin meriah dan agung. Akan tetapi, perlu juga diperhatikan bahwa masing-masing alat musik yang bergabung dalam suatu pertunjukan diposisikan sebagaimana mestinya. Dengan kata lain, masing-masing pemain alat musik harus mampu menahan dan menyesuaikan diri dengan yang lain, sehingga keharmonisan dalam musik bisa tercapai dan membawa pengaruh yang diinginkan pada pendengarnya.

Istilah timbre tidak hanya dikenal dalam dunia musik, tetapi juga bersifat analogis untuk kehidupan manusia. Keunikan yang ditemukan bukan dalam segi fisik saja, tetapi juga dalam hal psikis, atau jasmani dan juga rohani. Tidak ada manusia yang sama, baik secara fisik maupun psikis, sekalipun mereka adalah kembar. ${ }^{38}$ Dengan kata lain, bahwa setiap manusia mempunyai kenikan dan keunggulannya masing-masing. Ada orang yang unggul dalam pergaulan, berbakat untuk memimpin suatu kegiatan, tetapi ada juga orang yang unggul dalam bidang lain seperti dekorasi, gambar, musik, dan desain. Keindahan bisa terbentuk ketika bakat dan kemampuan yang dimiliki seseorang dibagikan kepada orang lain, yang akhirnya dapat membawa pada suatu harmoni warna dalam kebersamaan.

\section{Lirik}

Beberapa literatur yang membahas tentang kekuatan musik tidak memasukkan lirik sebagai salah satu elemen musik. Akan tetapi, saya merasa hal ini penting untuk dipandang sebagai bagian dari kekuatan musik. Syair atau lirik mempunyai kekuatan yang serupa dengan elemen-elemen musik lain (melodi, ritme, harmoni, tempo, dinamika, dan warna suara), karena mampu menarik perhatian para pendengarnya. Elemen ini bahkan dapat dikatakan sebagai bagian yang paling langsung mengungkapkan isi sebuah lagu, tanpa mengecualikan elemen-elemen lainnya. Lirik merupakan suatu 
karya sastra yang berisi curahan perasaan pribadi, berupa susunan kata dalam sebuah lagu. ${ }^{39}$ Lirik juga bisa diartikan sebagai bentuk ekpresi seseorang tentang suatu hal yang telah dilihat, didengar, atau dialaminya. Itu berarti bahwa melalui lirik, seseorang dapat mengungkapkan isi hatinya mengenai suatu pengalaman, baik tentang kegelisahan, kekecewaan, kecemasan, maupun kegembiraan.

Lirik dalam lagu sangat menentukan bagaimana ia diterima dan 'disukai' pendengar. Lirik yang bertema cinta, misalnya, banyak diminati kaum muda yang masih bersemangat. Sementara itu, lirik yang mengungkapkan nostalgia sering disukai kebanyakan generasi tua yang ingin mengenang kembali masa lalunya. Akan tetapi, tidak tertutup kemungkinan pula bagi kaum muda untuk menyukai lagu-lagu berlirik nostalgia, karena lagu-lagu demikian mampu menghadirkan kembali pengalaman-pengalaman di masa lalu ke dalam kesadaran. Dengan lagu berlirik nostalgia, seseorang bisa terpancing masuk ke dalam pengalamanpengalaman masa lalu, entah itu pengalaman yang menyenangkan maupun yang menyedihkan, karena pada dasarnya manusia dekat pada hal-hal real yang menyangkut pengalaman dalam kehidupannya.

Lirik yang dibawakan dalam sebuah lagu merupakan sarana yang bisa dipandang efektif menyuarakan sesuatu, baik yang bersifat positif maupun negatif. Bersifat positif, artinya sebuah lagu dengan lirik tertentu dapat mengundang orang untuk merefleksikan hidupnya. Lagu Ebiet G. Ade berjudul Berita kepada Kawan, misalnya, memuat suatu pesan mengenai bencana yang melanda manusia. Lewat lagu itu, pendengar diundang untuk merenungkan perbuatannya terhadap alam dalam perilaku-perilaku yang mungkin tidak bersahabat. Lirik yang negatif tecermin dalam lagulagu yang bersifat memprotes dan memberontak terhadap aturan, dan hal ini bisa mempengaruhi banyak orang, khususnya kaum muda, yang masih cenderung menerima begitu saja apa yang didengarnya. Oleh sebab itu, dapat dikatakan bahwa lirik dalam sebuah lagu mempunyai kekuatan untuk mempengaruhi pendengarnya.

Dalam prosiding Lyrics, Music, and Emotions, pernah dibahas bahwa kombinasi antara musik dan lirik dapat mempengaruhi emosi para pendengar, dan bahkan mampu menciptakan perasaan yang dalam. ${ }^{40}$ Itu berarti bahwa lagu yang bisa sangat kuat memancing emosi para pendengarnya ialah lagu yang benar-benar memperhatikan syair atau 
liriknya. Plato pernah mengatakan bahwa musik merupakan salah satu bagian penting yang sangat mempengaruhi kehidupan manusia, khususnya kaum muda. Oleh karenanya, penting sekali untuk menata sedemikian rupa melodi serta lirik yang ada dalam lagu. Musik yang tidak mempunyai kata-kata atau lirik bahkan bisa disebut 'cacat'. ${ }^{41}$ Dengan kata lain, musik yang sempurna ialah musik yang mempunyai lirik serta melodi yang tertata dengan baik. Sementara itu, Schopenhauer cenderung lebih menekankan unsur musik dibanding lirik. Baginya, musik adalah unsur yang lebih utama, sedangkan kata-kata atau lirik hanyalah tambahan ${ }^{42}$ meskipun ada kemungkinan untuk menerima lirik sebagai bagian dari musik.

Dewasa ini, ada berbagai macam jenis musik yang dapat diakses, mulai dari musik instrumental sampai musik yang disertai lirik. Semua musik menawarkan keindahan, keunggulan, dan kegunaan kepada orang-orang yang mendengarkannya. ${ }^{43}$ Setiap orang bebas menentukan pilihannya masing-masing dalam hal mendengarkan musik atau lagu. Lagulagu tertentu cenderung disukai jika berkaitan dengan situasi yang dialami manusia sehari-hari. Sementara itu, ada lagu-lagu yang sengaja diciptakan untuk mempengaruhi pendengar menjadi lebih baik atau menjadi lebih buruk. Dalam hal ini, musik tidak lagi bersifat netral dalam dirinya sendiri, melainkan dipengaruhi orang yang menciptakannya.

Lirik dalam lagu bisa sangat mempengaruhi bagaimana lagu itu kemudian disukai orang, sehingga penting untuk menyusun dan menatanya. Lirik-lirik lagu yang bermakna positif, dalam konteks tulisan ini, diutamakan dibanding lirik-lirik negatif. Tujuannya ialah pendengar mampu mengalami transformasi ke arah yang positif pula. Singkatnya, kekuatan lirik dalam musik atau lagu akan berpengaruh dalam mempengaruhi pendengar melalui keindahan yang sekaligus juga menghibur.

\section{Musik dan Karakter Manusia}

Pendidikan musik di Yunani dapat dipakai sebagai dasar untuk mendukung penggunaan musik dalam pendidikan karakter kaum muda di Indonesia. Yang merupakan masalah kini ialah bahwa pengetahuan masyarat mengenai musik masih cenderung sebagai hiburan daripada sarana pendidikan. Tidak jarang orang tua menganggap pendidikan musik sebagai hal yang tidak penting. Dengan kata lain, pendidikan musik sering dianggap sebagai sarana pengembangan bakat anak-anak 
yang bahkan dipertanyakan kegunaannya untuk mendukung pencarian nafkah. Sementara itu, pendidikan musik, dari pembahasan di atas, pada dasarnya bisa diarahkan untuk memampukan seseorang memahami nilainilai kebaikan, dan terutama untuk mampu membedakan antara yang baik dan yang buruk. Pembelajaran musik bisa membuat seseorang lebih peka terhadap kebaikan dan keburukan karena sifat pelatihan-pelatihan yang mendasarinya, misalnya, dalam mengapresiasi keindahan. Dengan pendidikan musik, anak-anak diajar untuk mengikuti aturan-aturan yang ada dalam pelatihan musik, sehingga mereka terbiasa menggunakan kepekaan dalam kesadaran untuk menemukan keindahan serta kebaikan.

Pendidikan karakter melalui musik terinspirasi oleh pandangan Pytagoras mengenai pentingnya musik demi keharmonisan jiwa. Dikatakannya, bahwa pendidikan ini diberikan melalui pelatihan-pelatihan musik, antara lain melalui pembelajaran alat musik harpa serta pembacaan puisi yang diiringi sitar dan seruling. ${ }^{44}$ Dengan pembelajaran musik, seseorang dapat memahami makna keteraturan, keindahan, dan kehalusan jiwa, sehingga secara tidak langsung karakter seseorang pun dibentuk untuk menampakkan kebaikan. Dasar dan alasan pemanfaaatan musik dalam pengembangan karakter kaum muda yang dijelaskan di atas sangat kuat, mengingat bahwa kaum muda sangat suka mendengarkan atau bermain musik. Kecenderungan ini mesti dimanfaatkan sebagai pintu masuk untuk mengarahkan pendidikan anak-anak kepada kebaikan dan keindahan.

\section{Musik Menembus Batas}

Musik merupakan sebentuk seni yang memberi warna tersendiri dalam kehidupan manusia. Seseorang dapat merasakan kedamaian, kehangatan, dan kelemahlembutan setelah mendengarkan musik atau lagu tertentu. Manusia dalam hal ini dapat merasakan kenikmatan jenis-jenis musik tertentu, meskipun alasan mengapa ia dapat merasakan hal-hal itu sering kali sulit dijelaskan. Musik dari zaman dahulu hingga sekarang masih menyimpan misteri, namun pengalaman-pengalaman manusia menunjukkan bahwa musik mampu memberikan efek tertentu bagi karakter manusia, entah menjadi baik atau menjadi buruk.

Kekuatan musik seperti ditelaah di atas mampu menembus batas-batas cakrawala kehidupan manusia yang satu dan manusia yang 
lain. Dalam arti ini, musik memiliki potensi untuk mempersatukan umat manusia yang berbeda-beda karakternya. Kegiatan-kegiatan manusia secara publik sering memanfaatkan kekuatan musik, dan juga para penyanyi tampil membawakan beberapa lagu antara lain untuk menarik pendukung dan mempengaruhi mereka. Dalam kegiatan-kegiatan publik itu, orangorang dari berbagai latar belakang dapat menikmati musik dan lagu yang dibawakan.

\section{Musik Menumbubkan Rasa Nasionalisme}

Cita rasa musikal membawa korelasi dengan rasa nasionalisme. Jenis musik tertentu dapat memengaruhi masyarakat untuk semakin mencintai tanah air. Contoh lagu-lagu nasional adalah Bagimu Negri, Bangun Pemudi Pemuda, dan Berkibarlah Benderaku. Lagu nasional merupakan lagu yang berbahasa Indonesia, diciptakan pada masa kemerdekaan, dan isi serta jiwa lagu tersebut menggambarkan peristiwa-peristiwa nasional. Lagu nasional dapat memengaruhi dan memupuk rasa nasionalisme bagi masyarakat. Penggunaan lagu-lagu nasional juga merupakan salah satu cara untuk membentuk karakter warga suatu bangsa serta menumbuhkan rasa cinta terhadap tanah air. Dalam praktik pendidikan, ada masa ketika lagulagu nasional kurang diajarkan kepada murid-murid di sekolah-sekolah, dengan alasan yang masih perlu direfleksikan di lingkup masing-masing sekolah. Lagu-lagu nasional pada dasarnya memiliki efek yang baik dalam proses pembelajaran, khususnya untuk membentuk karakter murid agar menjadi pribadi yang memiliki rasa nasionalisme tinggi. Dalam hal ini, lagu-lagu nasional memiliki korelasi erat dengan proses pembentukan karakter suatu bangsa. Ada beberapa elemen yang dapat memupuk rasa nasionalisme, yang diungkapkan. melalui syair, nada, dan tempo lagu. Lagu Indonesia Raya, misalnya, dapat membantu warga negara Indonesia untuk semakin memahami dan menghargai perjuangan para pahlawan yang telah mempertahankan negara dari penjajahan bangsa asing. Dari syair dan nada lagu yang dilantunkan, orang yang mendengarnya atau menyanyikannya dapat terdorong untuk semakin mencintai tanah air dan mengapresiasi perjuangan di masa lalu dalam mempertahankan negara. Melalui lagu tersebut juga orang diingatkan untuk mengenang perjuangan para pahlawan 
yang telah merebut kemerdekaan Indonesia, sekaligus dimotivasi untuk memupuk rasa nasionalisme dalam rangka mempertahankan kesatuan bangsa.

\section{Musik Menumbubkan Rasa Cinta Kasih}

Karakter yang diwarnai rasa cinta kasih merupakan hal yang berhadapan dengan egoisme dan individualisme yang merupakan ciri khas manusia dewasa ini, namun juga adalah realitas yang sangat real dalam kehidupan sehari-hari. Salah satu penyebabnya adalah perkembangan teknologi yang semakin membuat manusia menjauh dan melupakan orang lain. Berangkat dari keprihatinan ini, institusi-institusi pendidikan mulai mencari cara agar murid-muridnya menjadi manusia yang memiliki karakter berkualitas. Kualitas yang dimaksud ialah kematangan atau kedewasaan pribadi untuk melihat "yang lain" sebagai bagian dari realitas bersama di dunia. Musik dapat menjadi jembatan untuk mempertemukan dan mempersatukan individu yang satu dengan individu yang lain.

Untuk mewujudkan keterkaitan semacam ini, di dunia pendidikan adalah penting bahwa para orang tua dan pendidik memperkenalkan nilai kebersamaan dengan cara memperdengarkan musik yang dapat meningkatkan kepedulian satu terhadap yang lain. Para orang tua dan pendidik dapat melakukannya dengan menerapkan kebiasaan mendengarkan jenis-jenis musik yang dapat mengembangkan karakter anak ke arah kebaikan. Untuk menerapkan hal ini dibutuhkan kriteria musikalitas yang positif bagi para orang tua dan pendidik dalam membimbing kaum muda, yakni dengan menyodorkan pilihan dan membantu mereka memilih jenis musik untuk diapresiasi.

Pengembangan musik dalam pendidikan karakter manusia masih belum mendapat tempat yang memadai di dunia pendidikan dewasa ini. Kebanyakan musik yang laku di antara kaum muda masih yang bertema cinta atau putus cinta, padahal kalau tema-tema musik diarahkan pada nilai-nilai kebaikan serta keindahan, kaum muda bisa sangat terbantu mengembangkan dan menerima karakter yang bermanfaat bagi kehidupan mereka.

\section{Menjadi Manusia Otentik Melalui Musik}

Seni secara luas sebagai sebuah bidang pengetahuan manusiawi bisa dipergunakan untuk membantu menafsirkan dan menyingkapkan 
makna-makna baru dalam kehidupan manusia. Pada bidang pengetahuan seni musik, ritme, nada, syair, dan elemen-elemen lain dapat dipergunakan sebagai bahan kajian teoretis yang dianalisis dan dieksplorasi lebih lanjut. Selain pada tataran teoretis, musik juga berperan sebagai bagian dari pengalaman manusia yang sifatnya dinamis. Musik sebagai sebuah bidang pengetahuan dapat membantu menyingkapkan martabat manusia dalam pengalaman kehidupan dan membentuk pengungkapan eksistensi manusia menuju kebaikan. Melalui musik, orang bisa mengalami suatu ritme kehidupan yang membawa keteraturan dan harmoni. Sensibilitas ketika memperoleh rangsangan dari atau setelah mendengarkan atau memainkan alat musik dapat menumbuhkan kepekaan seseorang sebagai manusia yang berkarakter.

Musik, sebagai ekspresi jiwa, juga mampu mengantar orang pada kesadaran humanis, maka aktivitas yang melibatkan musik bisa menghadirkan respon positif dalam kesadaran manusia. Beberapa jenis musik dapat memotivasi orang untuk memperjuangkan kehidupan yang dinamis, damai, tenang, dan lebih baik. Karakter perikemanusiaan dapat ditonjolkan sehingga pengabdian diarahkan pada kepentingan bersama. Akan tetapi, penerapan musik dalam kaitan dengan pembentukan karakter juga dapat menghasilkan ketegangan, terutama ketika efeknya negatif. Dampak negatif ini muncul dalam emosi, tindakan, dan perilaku fisiologis. Perlu dipelajari karakter yang bisa dimunculkan jenis-jenis musik tertentu, yang dapat mempengaruhi tanggapan fisik, fisiologis, dan kognitif. Masih diperlukan penelitian lebih mendalam tentang faktor-faktor musik yang bisa mempengaruhi kesehatan diri seseorang. Sebagai contoh, jenis musik rock bisa menimbulkan respon yang keras, memberontak, atau mendobrak keteraturan. Bentuk yang lebih radikal jenis musik ini bahkan bisa merusak keadaan mental seseorang atau sekelompok orang. Dampak negatif yang mungkin dimunculkan dalam musik meliputi perasaan yang tidak menyenangkan, perubahan pola pernafasan, detak jantung, dan tekanan darah. Musik tertentu juga dapat menciptakan ketegangan otot dan meningkatkan dorongan bagi gerak aktif tubuh. Musik yang keras dan kuat, dalam hal tertentu, bahkan bisa meningkatkan suhu tubuh seseorang. ${ }^{45}$

Dari berbagai kemungkinan pengaruh musik pada pembentukan karakter di atas, dapat dilihat bahwa musik dapat dipergunakan lebih 
optimal jika dieksplorasi dengan benar. Manusia adalah makhluk yang menyimpan banyak keutamaan, dan untuk menyingkapkan karakternya diperlukan pendampingan yang berkelanjutan dan serius. Musik dapat menjadi sarana yang sekaligus menyenangkan ketika dimanfaatkan bagi pembentukan individu-individu yang berkarakter baik.

\section{Penutup}

Musik memiliki daya transformatif, dan kekuatan transformatif ini dapat mengarahkan serta mengubah karakter manusia yang mendengarkannya. Kekuatan musik seperti ditemukan lewat elemenelemennya di atas bisa membentuk karakter manusia ke arah kebaikan. Musik juga membawa korelasi tertentu dengan tubuh manusia. Musik dan tubuh memiliki keterkaitan satu sama lain dengan cara tertentu yang bisa diamati pada diri manusia yang mendengarkan dan menanggapinya. Ketika mendengarkan musik, seseorang tidak hanya terfokus pada pikirannya, tetapi juga pada kesadaran dirinya yang langsung menikmati musik yang sedang didengarkannya.

Dengan menambah pengetahuan dan mempelajari pengaruh elemen-elemen musik, manusia dapat mengembangkan sikap menghargai satu sama lain. Ia bisa menjadi lebih menyadari bahwa dalam diri orang lain pun terdapat keunikan tersendiri yang menangkap sisi berbeda musik. Dalam musik pun terdapat elemen-elemen dasar yang merupakan kekuatan, yang jika dipadukan akan menghasilkan suatu jenis musik yang indah dan menginspirasi. Elemen-elemen musik adalah bagian-bagian unik yang tidak dapat dijumpai dalam karya seni yang lain.

Pendidikan karakter selama ini merupakan tanggung jawab bersama orang tua, guru, dan masyarakat. Pendidikan karakter adalah proses pembelajaran yang memungkinkan anak atau murid dalam komunitas sekolah memahami, saling peduli, dan bertindak atas dasar nilai-nilai dalam etika seperti sopan santun, keadilan, kebajikan, dan tanggung jawab pada diri sendiri dan orang lain. Pendidikan karakter melalui musik merupakan salah satu cara yang memuat potensi besar dalam mendidik manusia di zaman sekarang, namun perlu diteliti lebih lanjut jenis musik yang dapat digunakan dalam rangka pendidikan karakter, yakni yang mampu memberi suasana pertumbuhan karakter seseorang menuju pribadi yang bermoral.

Kadang-kadang orang berpikir bagaimana pendidikan karakter melalui musik dapat diterapkan di Indonesia, sebab tampaknya pemerintah 
belum mengarahkan cara mendidik karakter dengan memanfaatkan kekuatan musik. Diperlukan kerja sama antara pemerintah dan institusiinstitusi pendidikan untuk turut serta aktif dalam pembentukan karakter kaum muda. Promosi jenis musik yang mengarahkan pada keindahan dan kebaikan perlu diperbanyak, sehingga tidak hanya fungsi menghibur, melainkan terutama fungsi positif musik pada karakter manusia bisa dipraktikkan dan mempengaruhi kehidupan.

\section{References:}

Cole, Basil. Music and Morals: A Theological Appraisal of the Moral and Psychological Effects of Music. New York: Alba House, 1993.

Copland, Aaron. What to Listen for in Music. London: Mcgraw-Hill Book Company, 1957.

Departemen Pendidikan dan Kebudayaan. Kamus Besar Bahasa Indonesia. Jakarta: Balai Pustaka, 1989.

Kamien, Roger. Music: An Appreciation. USA: The McGraw-Hill Companies, Inc., 1976.

Koesoema A, Doni. Pendidikan Karakter: Strategi Mendidik. Anak di Zaman Global. Jakarta: PT. Grasindo, 2007.

Machlis, Joseph. The Enjoyment of Music. New York: W.W. Norton \& Company Inc., 1970.

Mihalcea, Rada \& Carlo Strapparava. Lyrics, Music, and Emotions. Proceeding of the 2012 Joint Conference on Empirical Methods in Natural Language Processing and Computational Natural Language Learning, Jeju Island, Korea, 12-14 July 2012.

Mucci, Richard, \& Kate Mucci. The Healing Sound of Music. Scotland: Findhorn Press, 2000.

Naissaban, Ladislaus. Para Psikolog Terkemuka Dunia: Riwayat Hidup, Pokok Pikiran, dan Karya. Jakarta: Grasindo, 2004.

Otenieli Daeli, Onesius. Signifikasi Musik dalam Inkulturasi. Tesis: Fakultas Filsafat, Universitas Katolik Parahyangan, Bandung, 2002.

Parto, Suhardjo. Musik Seni Barat dan Sumber Daya Manusia. Yogyakarta: Pustaka Pelajar, 1996.

Young, Caroline \& Cyndie Koopsen. Spiritualitas, Kesehatan, dan Penyembuhan. Medan: Bina Media Perintis, 2007. 


\section{Endnotes:}

1 Mahasiswa pascasarjana Magister Ilmu Teologi, Fakultas Filsafat, Universitas Katolik Parahyangan, Bandung.

2 Bdk. Doni Koesoema A, Pendidikan Karakter: Strategi Mendidik Anak di Zaman Global, (Jakarta: PT. Grasindo, 2007) 90.

3 Lih. Departemen Pendidikan dan Kebudayaan, Kamus Besar Bahasa Indonesia, (Jakarta: Balai Pustaka, 1989) 389.

4 Ibid.

5 Emmanuel Mounier (1905- 1950) adalah seorang filsuf Perancis, teolog, serta penulis esai.

6 Bdk. Koesoema A., loc. cit.

7 Lih. Ladislaus Naissaban, Para Psikolog Terkemuka Dunia: Riwayat Hidup, Pokok Pikiran, dan Karya (Jakarta: Grasindo, 2004) 19-20.

8 Gregor Johann Mendel (1822 - 1884) adalah ilmuwan dan biarawan augustinian berbahasa Jerman Silesian yang terkenal sebagai pendiri baru ilmu dari genetika. Mendel menunjukkan bahwa warisan biologis gen tertentu sifat dalam tanaman kacang ercis mengikuti pola-pola tertentu, yang sekarang disebut Hukum Mendel.

9 Lih. Koesoema A., op. cit., 9.

10 Pendekatan yang menekankan pada nilai-nilai transenden yang dipercaya sebagai motor penggerak sejarah, baik bagi individu maupun bagi sebuah perubahan sosial.

11 Lih. Koesoema A, loc. cit.

12 Ibid.

13 Lih.Kate Mucci \& Richard Mucci, The Healing Sound of Music (Scotland: Findhorn Press, 2000) 101.

14 Lih.Aaron Copland, What to Listen for in Music (London: Mcgraw-Hill Book Company, 1957) 33.

15 Lih. Joseph Machlis, The Enjoyment of Music (New York: W.W. Norton \& Company Inc., 1970) 11-29.

16 Lih. Onesius Otenieli Daeli, Signifikasi Musik dalam Inkulturasi (Tesis: Fakultas Filsafat, Universitas Katolik Parahyangan, Bandung, 2002) 10.

17 Lih. Machlis, op. cit., 11.

18 Lih. Copland, op. cit., 49.

19 Adele (lahir di Tottenham, London, 5 Mei 1988) adalah penyanyi jazz \& soul serta penulis lagu dari Inggris yang memiliki suara kontraalto. Ia telah menerima banyak pengakuan baik komersial maupun kritis. Pada Grammy Awards 2009, Adele memenangkan penghargaan untuk Pendatang Baru Terbaik dan Penampilan Vokal Pop Terbaik.

20 Lih. Copland, op. cit., 51.

21 Lih. Machlis, op. cit., 20.

22 Lih. Suhardjo Parto, Musik Seni Barat dan Sumber Daya Manusia (Yogyakarta: Pustaka Pelajar, 1996) xi.

23 Lih. Daeli, op. cit., 15.

24 Ibid. 
25 Bdk. Machlis, op. cit., 15.

26 Ibid., 16.

27 Ibid., 17.

28 Lih. Roger Kamien, Music: An Appreciation (USA: The McGraw-Hill Companies, Inc., 1976) 34.

29 Lih. Machlis, op. cit., 24.

30 Ibid.

31 Ibid., 25.

32 Ibid.

33 Ibid.

34 Ibid.

35 Lih. Machlis, op. cit., 29-30.

36 Lih. Departemen Pendidikan dan Kebudayaan, op. cit., 947.

37 Lih. Copland, op. cit., 78.

38 Lih. Daeli, op. cit., 24.

39 Lih. Departemen Pendidikan dan Kebudayaan, op. cit., 528.

40 Lih. Rada Mihalcea \& Carlo Strapparava, Lyrics, Music, and Emotions. Proceeding of the 2012 Joint Conference on Empirical Methods in Natural Language Processing and Computational Natural Language Learning, Jeju Island, Korea, 12-14 July 2012: 590-599.

41 Bdk. Basic Cole, Music And Morals: A Theological Appraisal of the Moral and Psychological Effects of Music (New York: Alba House, 1993) 28.

42 Ibid., 105.

43 Lih. Daeli, op. cit., 32.

44 Bdk. Koesoema A, op. cit., 35.

45 Bdk. Caroline Young \& Cyndie Koopsen, Spiritualitas, Kesehatan, dan Penyembuban (Medan: Penerbit Bina Media Perintis, 2007) 166-168. 